\title{
Renin-Angiotensin System Inhibition in Conscious Sodium-Depleted Dogs
}

\author{
EFFECTS ON SYSTEMIC AND CORONARY HEMODYNAMICS
}

\author{
Chang-seng liang, Haralambos Gavras, and William B. Hood, Jr., \\ The Departments of Medicine and Pharmacology and the Cardiovascular \\ Institute, Boston University School of Medicine, the Cardiology and \\ Hypertension Departments of the Medical Service and Thorndike Memorial \\ Laboratories, Boston City Hospital, and the Departments of Medicine and \\ Clinical Research, University Hospital, Boston, Massachusetts 02118
}

\begin{abstract}
A B S T RACT The role of the renin-angiotensin system in the regulation of the systemic and coronary circulations during sodium depletion was studied in conscious normotensive dogs by i.v. administration of teprotide $(0.5 \mathrm{mg} / \mathrm{kg})$, an angiotensin-converting enzyme inhibitor, and saralasin $(0.05-5 \mu \mathrm{g} / \mathrm{kg}$ per $\mathrm{min}$ ), an angiotensin-receptor antagonist. Sodium depletion was produced by administering a low sodium diet and furosemide for 5 days. Administration of both teprotide and saralasin lowered systemic arterial blood pressure and total peripheral vascular resistance. Simultaneously, cardiac output increased, but left ventricular end-diastolic pressure, $d \mathrm{P} / d \mathrm{t}$, and $d \mathrm{P} / d \mathrm{t} / \mathrm{P}$ did not change significantly. Furthermore, both agents reduced diastolic coronary vascular resistance and increased coronary blood flow, but did not affect myocardial oxygen consumption, left ventricular work, or myocardial efficiency. These systemic and coronary vasodilator effects of teprotide and saralasin, however, were not observed in normal dogs on a regular sodium diet; in this group, the only effect noted was a slight increase in arterial pressure during saralasin infusion. Arterial plasma concentration of norepinephrine did not differ between normal and sodiumdepleted dogs, nor did it change significantly after teprotide administration. These results suggest that, during salt depletion, angiotensin II exerts an active vasoconstrictor action on the systemic and coronary
\end{abstract}

This study was presented in part at the 27th Annual Scientific Sessions of the American College of Cardiology, Anaheim, Calif., March 1978.

Dr. Gavras is an American Heart Association Established Investigator.

Received for publication 28 July 1977 and in revised form 11 November 1977. vessels, but has no significant effects on myocardial contractility or energetics. It also appears likely that the increase in cardiac output observed in sodiumdepleted dogs after angiotensin inhibition was caused, at least in part, by the decrease in systemic arterial pressure.

\section{INTRODUCTION}

Sodium depletion increases plasma renin activity (PRA) ${ }^{1}$ and blood angiotensin II concentration (1-3), indicating an activation of the renin-angiotensin system. This increase in angiotensin II concentration probably plays an important role in the maintenance of normal arterial blood pressure during salt depletion, because the arterial blood pressure decreases under these conditions after administration of saralasin (1-sarcosine-8-alanine-angiotensin II; P113) (2-7), teprotide (SQ 20,881) (7-10), and SQ 14,225 (11). Saralasin is a competitive receptor antagonist of angiotensin II $(4,12,13)$, whereas the latter two agents inhibit angiotensin-converting enzyme, which converts angiotensin $I$ to the biologically active angiotensin II $(8,13-16)$. Because angiotensin II is one of the most potent vasoconstrictors known (17, 18), a decrease in arterial blood pressure after angiotensin inhibition presumably is due to elimination of the angiotensin-induced vasoconstriction. However, angiotensin II also exerts a positive inotropic action on the heart $(19,20)$, the abolition of which may lower the arterial pressure. Previous investigators $(9,10)$ have shown that cardiac output de-

\footnotetext{
${ }^{1}$ Abbreviation used in this paper: PRA, plasma renin activity.
} 
creased in anesthetized salt-deprived rats after teprotide administration. The physiologic role of the renin-angiotensin system on myocardial contractility during salt depletion, however, has not been investigated.

The present study was undertaken to determine the effects of saralasin and teprotide on cardiac output, myocardial mechanical function, and total peripheral vascular resistance in salt-depleted conscious dogs. Also studied was the possible role of the reninangiotensin system in the regulation of coronary circulation during salt depletion. Angiotensin II may affect the coronary blood flow and vascular resistance either directly by its coronary vasoconstrictor action or indirectly by systemic vasoconstriction, which increases cardiac work and myocardial oxygen consumption $(20,21)$. Furthermore, because saralasin may exert a dose-dependent agonistic action on angiotensin receptors $(12,22,23)$, three doses of saralasin were administered. Results of this study indicate that angiotensin II exerts an active vasoconstrictor action on the systemic and coronary vessels during salt depletion, but has no significant effect on myocardial contractility or energetics.

\section{METHODS}

Adult male beagles between 6.6 and $15.5 \mathrm{~kg}$ were studied. Salt depletion was produced in 15 dogs by a low salt diet (h/d Dietary Animal Food, Riviana Foods, Inc., Hills Division, Topeka, Kan.), which provides 5-8 meq sodium daily, and by administration of furosemide $(10 \mathrm{mg}$ i.m. twice a day) for 5 days. A control group of 14 dogs was placed on the same diet, to which $2.5 \mathrm{~g}$ sodium chloride was added, for 5 days. Water was available ad lib. All dogs were kept in individual metabolic cages. Urine was collected each morning to determine the daily excretion of sodium, using a Radiometer flame photometer FLM2 (Rainin Instrument Co. Inc., Brighton, Mass.); sodium balance was recorded daily.

For the hemodynamic study, the animals were sedated with morphine sulfate ( $1 \mathrm{mg} / \mathrm{kg}$ subcutaneously) and placed on their sides with limbs lightly restrained. Under local lidocaine anesthesia, the aorta and the coronary sinus were cannulated with French 8 Cournand catheters and the pulmonary artery with a French 7 Swan-Ganz catheter (Edwards Laboratories, Inc., Santa Ana, Calif.). The aortic catheter was inserted via a femoral artery. Both coronary sinus and SwanGanz catheters were inserted under fluoroscopic guidance via external jugular veins. All catheters were connected via Statham P23Db pressure transducers to a multichannel Brush 480 recorder. (Gould, Inc., Instrument Systems Div., Cleveland, Ohio) for measuring blood pressures and heart rate.

The left ventricle was cannulated via the left carotid artery by a Millar transducer-tip catheter (Millar Instrument, Inc., Houston, Tex.) for measuring left ventricular enddiastolic and systolic pressures, and the first derivative of left ventricular pressure $(d \mathrm{P} / d \mathrm{t})$. The ratio of $d \mathrm{P} / d \mathrm{t}$ to a developed left ventricular pressure of $50 \mathrm{~mm} \mathrm{Hg}$ was calculated. This pressure occurred during isovolumic systole, and this ratio is referred to as $d \mathrm{P} / d \mathrm{t} / \mathrm{P}$.

Cardiac output was determined by the indocyanine green
(Cardio-Green) dye dilution technique (24), using a Gilford model 140 cardiac output system (Gilford Instrument Laboratories Inc., Oberlin, Ohio). Cardiac output was divided into the mean systemic arterial pressure to yield the total peripheral vascular resistance. Arterial blood samples were taken for measuring $\mathrm{pH}, \mathrm{pO}_{2}$, and $\mathrm{pCO}_{2}$ on a Radiometer PHM71 Acid Base Analyzer (Rainin Instrument Co. Inc., Brighton, Mass.). Arterial and coronary sinus blood samples were obtained for measuring oxygen content by a gas chromatographic method (25).

Coronary blood flow was measured by a 4-aminoantipyrine indicator method $(26,27)$. Diastolic coronary vascular resistance (CVRd), left ventricular work (LVW), myocardial oxygen consumption $\left(\mathrm{MVO}_{2}\right)$, and myocardial efficiency (ME) were calculated as follows (28):

$$
\begin{aligned}
\operatorname{CVRd}\left(\text { dyn } \cdot \mathrm{s} \cdot \mathrm{cm}^{-5}\right) & =\frac{\mathrm{Adm}-\mathrm{CVm}}{\mathrm{CBF} \times 0.75} \times \mathrm{DFP} \times 1,332 ; \\
\mathrm{LVW}(\mathrm{kg} \cdot \mathrm{m} / 100 \mathrm{~g} / \mathrm{min}) & =\frac{\mathrm{LVsm} \times \dot{\mathrm{Q}} \times 136}{100 \times \mathrm{W}} ; \\
\mathrm{MVO}_{2}(\mathrm{ml} / 100 \mathrm{~g} / \mathrm{min}) & =\mathrm{CBF} \times\left(\mathrm{C}_{\mathrm{a}} \mathrm{O}_{2}-\mathrm{C}_{\mathrm{cs}} \mathrm{O}_{2}\right) \div 1,000 ; \\
\mathrm{ME}(\%) & =\frac{\mathrm{LVW}}{\mathrm{MVO}_{2} \times 2.06} \times 100 ;
\end{aligned}
$$

where Adm is arterial mean diastolic pressure, $\mathrm{mm} \mathrm{Hg} ; \mathrm{CVm}$, coronary sinus mean pressure, $\mathrm{mm} \mathrm{Hg}$; DFP, coronary diastolic inflow period, s/min; CBF, coronary blood flow, $\mathrm{ml} / 100 \mathrm{~g} / \mathrm{min}$; LVsm, left ventricular systolic mean pressure, $\mathrm{mm} \mathrm{Hg;} \dot{\mathrm{Q}}$, cardiac output, liters/min; W, left ventricular weight determined at post-mortem, $\mathrm{g} ; \mathrm{C}_{\mathrm{a}} \mathrm{O}_{2}$, femoral arterial oxygen content, ml/liter; $\mathrm{C}_{\mathrm{cs}} \mathrm{O}_{2}$, coronary sinus oxygen content, $\mathrm{ml} / \mathrm{liter}$

PRA (29) was measured in both normal and sodium-depleted dogs. After a 20-min control period during which systemic and coronary hemodynamic measurements were obtained, angiotensin inhibition was induced by administration of either teprotide or saralasin. Control systemic hemodynamic values, given in Results, represent averages of triplicate measurements. Arterial plasma norepinephrine concentrations (30) were measured before and $20 \mathrm{~min}$ after teprotide administration.

Teprotide $(0.5 \mathrm{mg} / \mathrm{kg})$ was injected i.v., and systemic hemodynamic measurements were repeated at 5-min intervals for $30 \mathrm{~min}$ thereafter. Coronary blood flow was determined $20 \mathrm{~min}$ after teprotide administration. Pharmacologic inhibition of angiotensin-converting enzyme was assessed by measuring aortic pressor responses to angiotensin I $\mathbf{~} 0.5$ $\mu \mathrm{g}$, Schwarz/Mann Div., Becton, Dickinson \& Co., Bioresearch, Inc., Orangeburg, N. Y.) given i.v. before, and 30 min after, teprotide administration.

Saralasin was administered by i.v. infusion at rates of $0.05,0.5$, and $5 \mu \mathrm{g} / \mathrm{kg}$ per $\mathrm{min}$, each for $20 \mathrm{~min}$. The agent was diluted serially with normal saline for each dose and infused at a rate of $0.229 \mathrm{ml} / \mathrm{min}$ with a Harvard pump (Harvard Apparatus Co., Inc., Millis, Mass.). At the time of each infusion, systemic hemodynamic measurements were obtained every $5 \mathrm{~min}$, and coronary blood flow every $20 \mathrm{~min}$. The pressor response to angiotensin II (0.5 $\mu$ g, i.v.; Hypertensin, CIBA Pharmaceutical Co. Summit, N. J.) was measured at the control period and at 20 min of each infusion to determine the degree of angiotensin II receptor blockade.

Experimental results were subjected to analysis of variance for repeated measures (31); the statistical significance of differences between the control and experimental values was 
determined by Dunnett's test (32), changes being considered statistically significant if $P$ values are $<0.05$. Student's $t$ test was used to determine the statistical significance of a difference between two means.

\section{RESULTS}

Effects of sodium depletion. A significant cumulative negative sodium balance $(-84 \pm 11 \mathrm{meq}$; mean $\pm \mathrm{SE} ; n=15)$ occurred in dogs that received a low sodium diet and furosemide. PRA was significantly higher in these sodium-depleted dogs $(19.4 \pm 4.4$ $\mathrm{ng} / \mathrm{ml}$ per $\mathrm{h})$ than in the normal controls $(6.2 \pm 1.6$ $\mathrm{ng} / \mathrm{ml}$ per $\mathrm{h}, n=14 ; P<0.05)$. Figs. 1 and 2 show that pressor responses to angiotensin I and II were attenuated by sodium depletion. Also, compared to those in normal dogs, cardiac output and left ventricular end-diastolic pressure were lower, and total peripheral vascular resistance higher, in sodium-depleted dogs (Tables I and II). Other hemodynamic parameters did not differ between the two groups. Arterial blood $\mathrm{pH}$ and gases were within the physiological range in both normal and sodium-depleted dogs and did not change significantly after administration of either teprotide or saralasin.

Effects of teprotide administration. Teprotide administration significantly reduced the arterial pressor response to angiotensin I (Fig. 1). In the sodiumdepleted dogs, administration of teprotide decreased systemic arterial pressure and total peripheral vascular resistance (Fig. 3, Table I). Cardiac output and stroke volume increased, but left ventricular end-diastolic pressure, $d \mathrm{P} / d \mathrm{t}$, and $d \mathrm{P} / d \mathrm{t} / \mathrm{P}$ did not change significantly. A small but significant increase in heart rate

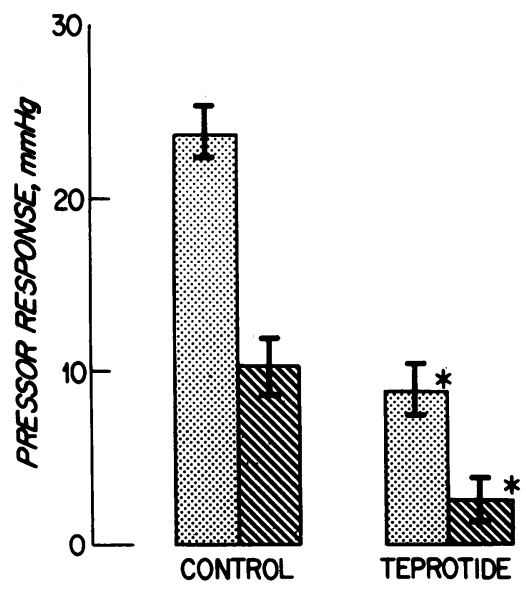

FIgURE 1 Changes in pressor response to angiotensin I $(0.5 \mu \mathrm{g}$, i.v.) after teprotide administration in nine normal (shaded columns) and eight sodium-depleted (hatched columns) dogs. Brackets indicate SE. Asterisks indicate values that are different from the control at $P<0.05$, as determined by Dunnett's test (32).

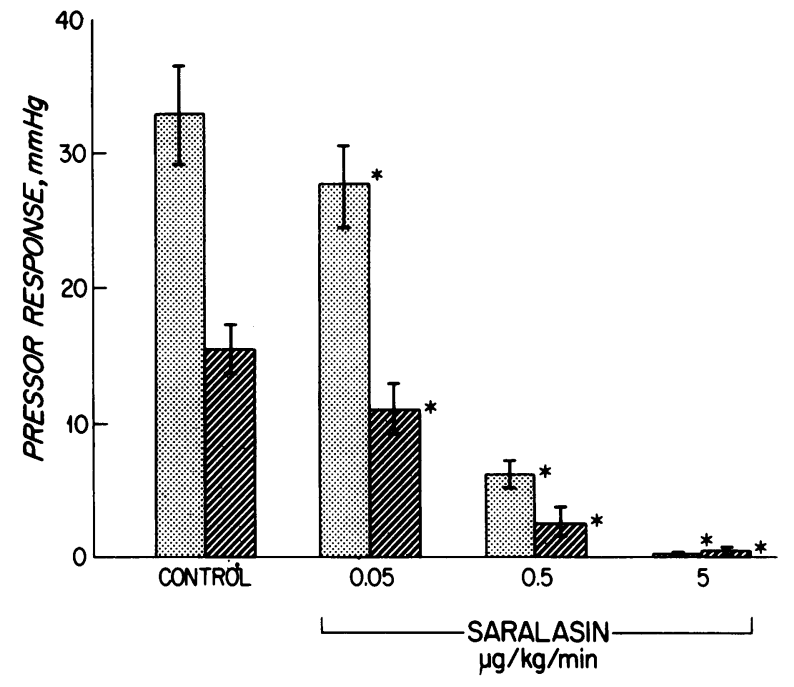

FIGURE 2 Changes in pressor response to angiotensin II $(0.5 \mu \mathrm{g}, \mathrm{i} . \mathrm{v}$.$) during successive saralasin infusions in$ five normal (shaded columns) and seven sodium-depleted (hatched columns) dogs. Brackets indicate SE. Asterisks indicate values that are different from the control at $P<0.05$, as determined by Dunnett's test (32).

occurred 25-30 min after teprotide administration (Fig. 3).

Teprotide also caused an increase in coronary blood flow in sodium-depleted dogs (Table III). Coronary sinus oxygen content increased $(44 \pm 7-78 \pm 7 \mathrm{ml} /$ liter $)$ and myocardial oxygen extraction decreased. Diastolic coronary vascular resistance fell, but neither left ventricular work nor myoçardial efficiency changed significantly.

These systemic and coronary vascular effects of teprotide, however, did not occur in the normal dogs (Tables I and III, Fig. 3). Arterial plasma norepinephrine concentration did not change significantly after teprotide administration in either normal $(0.35 \pm 0.11-$ $0.42 \pm 0.10 \mathrm{ng} / \mathrm{ml})$ or salt-depleted $(0.45 \pm 0.09-$ $0.38 \pm 0.05 \mathrm{ng} / \mathrm{ml}$ ) dogs.

Effects of saralasin infusions. Fig. 2 shows that the pressor response to angiotensin II progressively decreased after successive infusions of saralasin. As with teprotide administration, saralasin infusion decreased systemic arterial blood pressure and total peripheral vascular resistance in the sodium-depleted dogs (Fig. 4, Table II). Cardiac output increased slightly, but heart rate, stroke volume, left ventricular end-diastolic pressure, $d \mathrm{P} / d \mathrm{t}$, and $d \mathrm{P} / d \mathrm{t} / \mathrm{P}$ did not change significantly.

Coronary blood flow increased slightly in sodiumdepleted dogs during the lowest-dose infusion of saralasin but returned toward the preinfusion value at higher doses (Table IV). Diastolic coronary vascular resistance fell during all doses of saralasin infusion. 
TABLE I

Systemic Hemodynamic Effects of Teprotide in Normal and Sodium-Depleted Dogs

\begin{tabular}{|c|c|c|c|c|c|c|c|c|}
\hline & \multirow{2}{*}{$\begin{array}{l}\text { Mean } \\
\text { aortic } \\
\text { pressure }\end{array}$} & \multirow[b]{2}{*}{$\begin{array}{l}\text { Cardiac } \\
\text { output }\end{array}$} & \multirow[b]{2}{*}{$\begin{array}{l}\text { Heart } \\
\text { rate }\end{array}$} & \multirow[b]{2}{*}{$\begin{array}{l}\text { Stroke } \\
\text { volume }\end{array}$} & \multicolumn{3}{|c|}{ Left ventricular } & \multirow{2}{*}{$\begin{array}{l}\text { Total peripheral } \\
\text { vascular } \\
\text { resistance }\end{array}$} \\
\hline & & & & & $\begin{array}{l}\text { End-diastolic } \\
\text { pressure }\end{array}$ & $d \mathrm{P} / d \mathrm{t}$ & $d \mathrm{P} / d \mathrm{t} / \mathrm{P}$ & \\
\hline & $m m \mathrm{Hg}$ & $\mathrm{ml} / \mathrm{kg} / \mathrm{min}$ & beats/min & $\mathrm{ml} / \mathrm{kg}$ & $m m \mathrm{Hg}$ & $\begin{array}{c}m m \mathrm{Hg} / \mathrm{s} \\
\times 10^{-3}\end{array}$ & $s^{-1}$ & $\begin{array}{l}\text { dyn } \cdot s \cdot \mathrm{cm}^{-5} \\
\times 10^{-3}\end{array}$ \\
\hline \multicolumn{9}{|c|}{$\begin{array}{l}\text { Normal dogs }(n=9 \\
10.6 \pm 0.8 \mathrm{~kg})\end{array}$} \\
\hline $\begin{array}{c}\text { Teprotide } \\
\text { Sodium-deplet } \\
(n=8,9.1 \pm 0\end{array}$ & $121 \pm 3$ & $190 \pm 13$ & $70 \pm 4$ & $2.7 \pm 0.3$ & $7.8 \pm 1.1$ & $4.30 \pm 0.32$ & $60.0 \pm 2.3$ & $5.69 \pm 0.75$ \\
\hline Control & $116 \pm 4$ & $163 \pm 4$ & $76 \pm 8$ & $2.3 \pm 0.2$ & $5.9 \pm 0.9$ & $4.04 \pm 0.33$ & $55.1 \pm 1.8$ & $6.60 \pm 0.67$ \\
\hline Teprotide & $97 \pm 5^{*}$ & $198 \pm 11^{*}$ & $81 \pm 12$ & $2.7 \pm 0.2^{*}$ & $5.8 \pm 0.8$ & $4.08 \pm 0.43$ & $55.9 \pm 3.0$ & $4.72 \pm 0.66^{*}$ \\
\hline
\end{tabular}

Values are means $\pm \mathrm{SE}$ before and $20 \mathrm{~min}$ after i.v. administration of teprotide $(0.5 \mathrm{mg} / \mathrm{kg})$. The numbers of experiments and body weights of the dogs are given in parentheses after the headings for each experimental group.

* Values different from the control at $P<0.05$, as determined by Dunnett's test (32).

Myocardial oxygen extraction, myocardial oxygen consumption, left ventricular work, and myocardial efficiency did not change.

In normal dogs, saralasin infusion increased arterial pressure slightly during the middle-dose infusion of saralasin, but there were no changes in other hemodynamic parameters measured (Fig. 4, Tables II and IV).

\section{DISCUSSION}

Sodium depletion was produced in the present experiments by a low sodium intake and by ad- ministration of furosemide $(1,17,33)$. Hypovolemia probably was responsible for the reduced cardiac output and left ventricular end-diastolic pressure in these sodium-depleted dogs. The increased secretion of renin was evidenced in the present study by the increase in PRA and attenuated pressor responses to angiotensin injection. It has been well documented that the angiotensin pressor response correlates directly with sodium balance but inversely with PRA (34-36). This decrease in pressor activity of exogenous angiotensin during salt depletion may be the result

TABLE II

Systemic Hemodynamic Effects of Saralasin in Normal and Sodium-Depleted Dogs

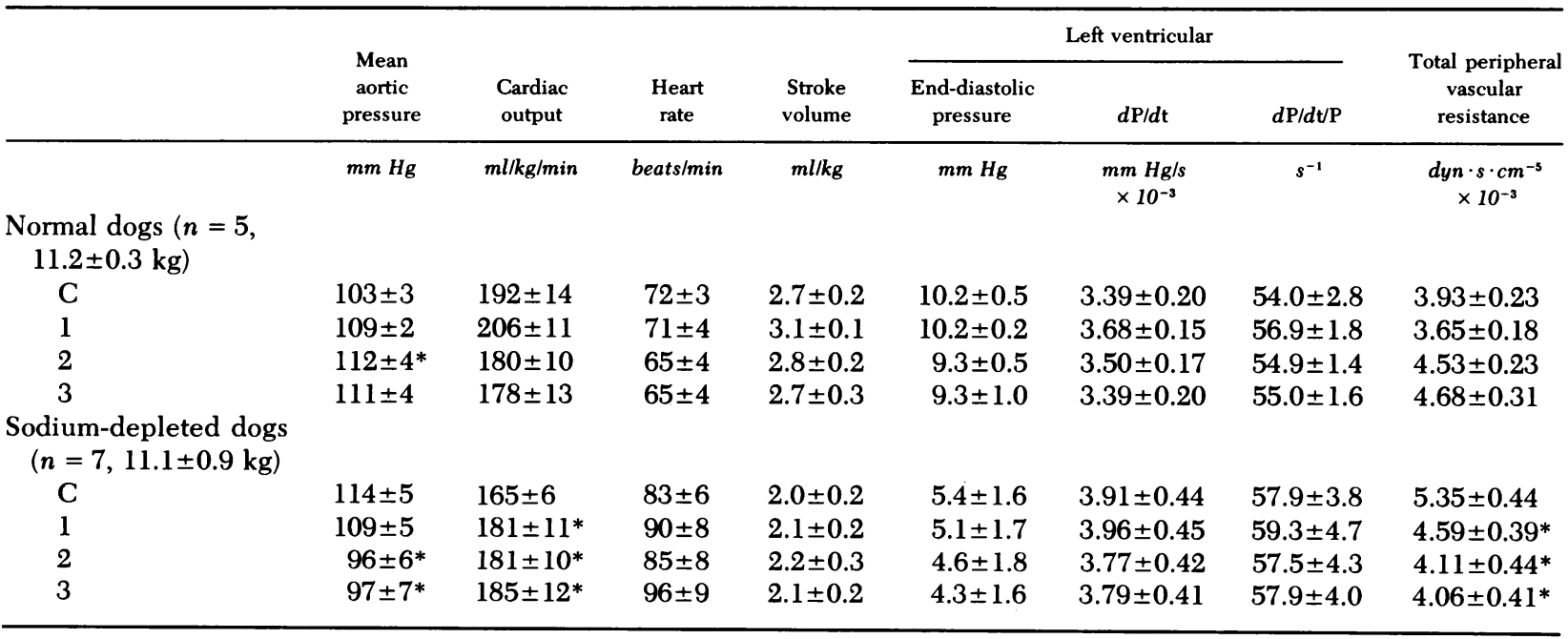

Values are means $\pm S E$ at a preinfusion control period $(\mathrm{C})$, and at $20 \mathrm{~min}$ during each of the successive saralasin infusions at rates of $0.05(1), 0.5(2)$, and $5.0(3) \mu \mathrm{g} / \mathrm{kg}$ per min. The numbers of experiments and body weights of the dogs are given in parentheses after the heading for each experimental group.

* Values different from the control at $P<0.05$, as determined by Dunnett's test (32). 


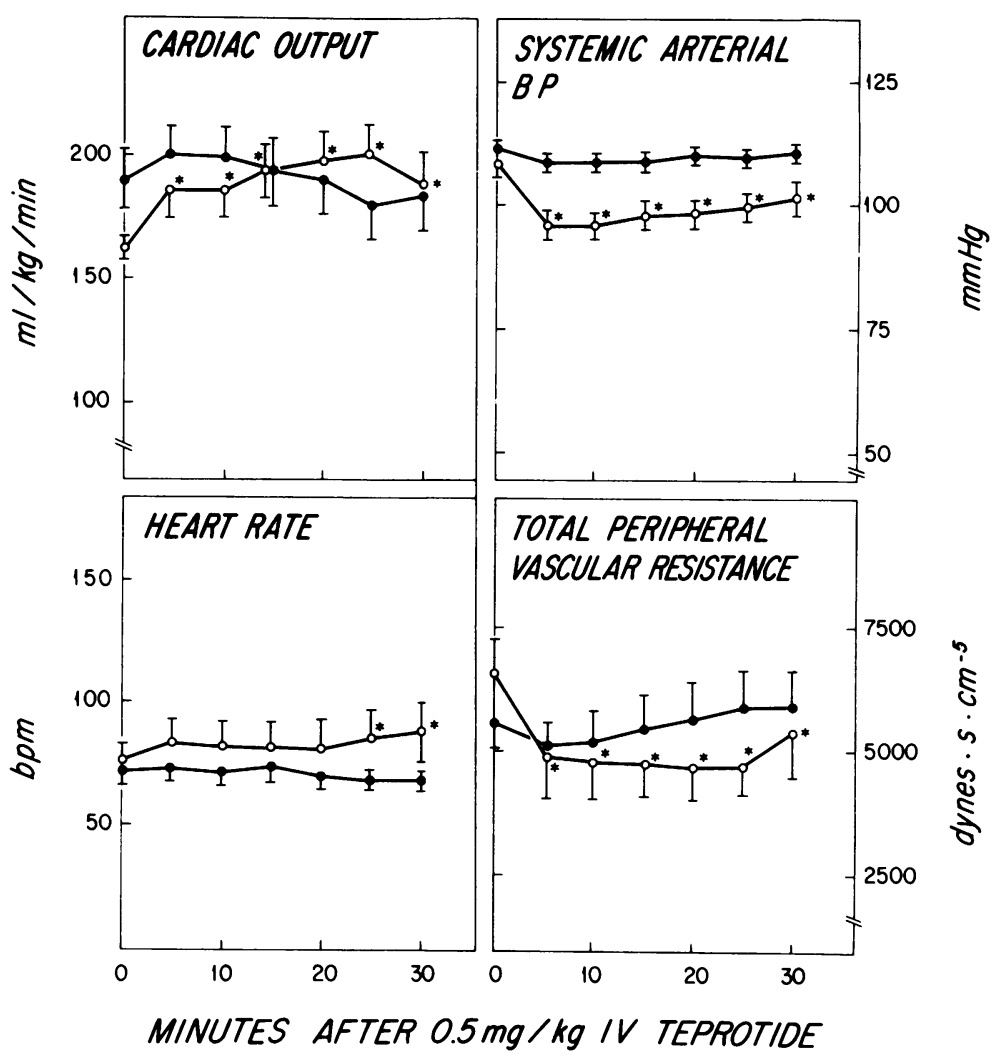

FIGURE 3 Changes in cardiac output, heart rate, systemic arterial blood pressure (BP), and total peripheral vascular resistance after teprotide administration in nine normal (closed circles) and eight sodium-depleted (open circles) dogs. Brackets indicate SE. Asterisks indicate values that are different from the control at $P<0.05$, as determined by Dunnett's test (32).

of occupation of receptor sites by endogenous angiotensin (36).

The present study confirms that the renin-angiotensin system plays an important role in blood pressure maintenance during salt depletion. Peripheral vascular resistance was elevated and cardiac output reduced during salt depletion, and administration of either teprotide or saralasin lowered peripheral vascular resistance and increased cardiac output. Furthermore, the results suggest that the main action of teprotide

TABLE III

Coronary Hemodynamic Effects of Teprotide in Normal and Sodium-Depleted Dogs

\begin{tabular}{|c|c|c|c|c|c|c|}
\hline & $\begin{array}{l}\text { Coronary } \\
\text { blood flow }\end{array}$ & $\begin{array}{l}\text { Myocardial } \\
\text { oxygen } \\
\text { extraction }\end{array}$ & $\begin{array}{l}\text { Diastolic } \\
\text { coronary } \\
\text { vascular } \\
\text { resistance }\end{array}$ & $\begin{array}{c}\text { Myocardial } \\
\text { oxygen } \\
\text { consumption }\end{array}$ & $\begin{array}{c}\text { Left } \\
\text { ventricular } \\
\text { work }\end{array}$ & $\begin{array}{l}\text { Mechanical } \\
\text { efficiency }\end{array}$ \\
\hline & $m l / 100 \mathrm{~g} / \mathrm{min}$ & $\%$ & $d y n \cdot s \cdot \mathrm{cm}^{-5} \times 10^{-3}$ & $\mathrm{ml} / 100 \mathrm{~g} / \mathrm{min}$ & $\mathrm{kg} \cdot \mathrm{m} / 100 \mathrm{~g} / \mathrm{min}$ & $\%$ \\
\hline \multicolumn{7}{|l|}{ Normal dogs } \\
\hline Control & $77 \pm 9$ & $76 \pm 3$ & $91.6 \pm 11.6$ & $9.9 \pm 0.9$ & $8.4 \pm 1.0$ & $42 \pm 5$ \\
\hline Teprotide & $72 \pm 10$ & $76 \pm 2$ & $99.7 \pm 15.2$ & $9.1 \pm 0.9$ & $8.3 \pm 1.3$ & $43 \pm 4$ \\
\hline \multicolumn{7}{|c|}{ Sodium-depleted dogs } \\
\hline Control & $69 \pm 5$ & $75 \pm 3$ & $96.0 \pm 7.0$ & $8.6 \pm 0.4$ & $6.4 \pm 0.3$ & $37 \pm 2$ \\
\hline Teprotide & $120 \pm 13^{*}$ & $50 \pm 7 *$ & $47.8 \pm 9.5^{*}$ & $9.9 \pm 0.8$ & $6.7 \pm 0.3$ & $35 \pm 2$ \\
\hline
\end{tabular}

Values are means $\pm \mathrm{SE}$ before and $20 \mathrm{~min}$ after i.v. administration of teprotide $(0.5 \mathrm{mg} / \mathrm{kg})$. The numbers of experiments and body weights of the dogs are the same as in Table I.

* Values different from the control at $P<0.05$, as determined by Dunnett's test (32). 


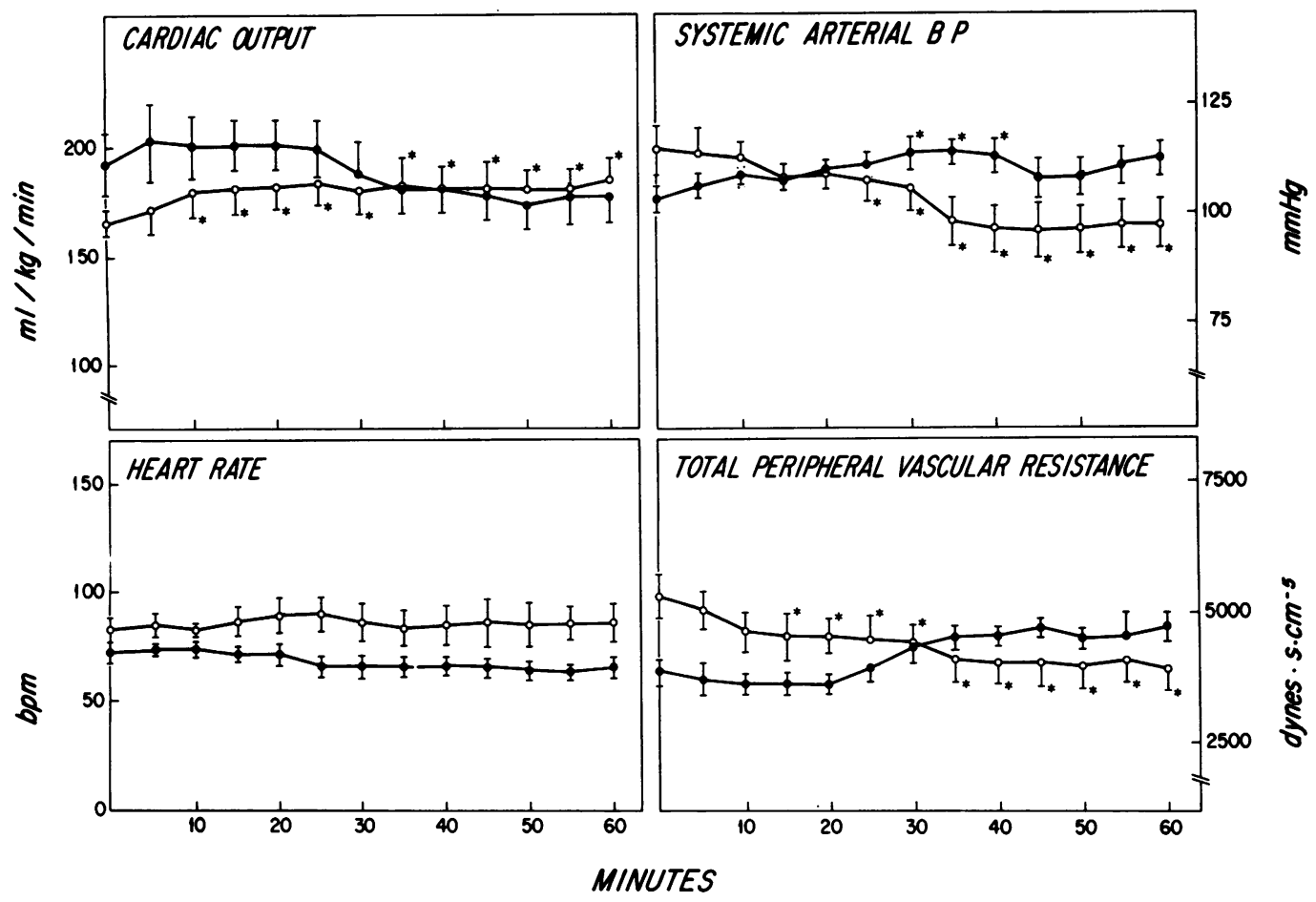

FIGURE 4 Changes in cardiac output, heart rate, systemic arterial blood pressure (BP), and total peripheral vascular resistance during successive saralasin infusions at rates of $0.05(0-20$ $\mathrm{min}$ ), $0.5(20-40 \mathrm{~min})$, and $5.0(40-60 \mathrm{~min}) \mu \mathrm{g} / \mathrm{kg}$ per $\mathrm{min}$ in five normal (closed circles) and seven sodium-depleted (open circles) dogs. Brackets indicate SE. Asterisks indicate values that are different from the control at $P<0.05$, as determined by Dunnett's test (32).

and saralasin during salt depletion is to reduce total peripheral vascular resistance, because measurements of myocardial contractility did not change sig- nificantly (Tables I and II). All of these effects were associated with a documented pharmacologic blockade of the renin-angiotensin system, as shown by the

TABLE IV

Coronary Hemodynamic Effects of Saralasin in Normal and Sodium-Depleted Dogs

\begin{tabular}{|c|c|c|c|c|c|c|}
\hline & $\begin{array}{l}\text { Coronary } \\
\text { blood flow }\end{array}$ & $\begin{array}{l}\text { Myocardial } \\
\text { oxygen } \\
\text { extraction }\end{array}$ & $\begin{array}{l}\text { Diastolic } \\
\text { coronary } \\
\text { vascular } \\
\text { resistance }\end{array}$ & $\begin{array}{c}\text { Myocardial } \\
\text { oxygen } \\
\text { consumption }\end{array}$ & $\begin{array}{c}\text { Left } \\
\text { ventricular } \\
\text { work }\end{array}$ & $\begin{array}{l}\text { Mechanical } \\
\text { efficiency }\end{array}$ \\
\hline & $\mathrm{ml} / 100 \mathrm{~g} / \mathrm{min}$ & $\%$ & $d y n \cdot s \cdot \mathrm{cm}^{-5} \times 10^{-3}$ & $\mathrm{ml} / 100 \mathrm{~g} / \mathrm{min}$ & $\mathrm{kg} \cdot \mathrm{m} / 100 \mathrm{~g} / \mathrm{min}$ & $\%$ \\
\hline \multicolumn{7}{|c|}{ Normal dogs } \\
\hline $\mathrm{C}$ & $79 \pm 8$ & $64 \pm 7$ & $73.5 \pm 12.1$ & $8.4 \pm 0.8$ & $6.8 \pm 0.5$ & $42 \pm 6$ \\
\hline 1 & $80 \pm 4$ & $65 \pm 5$ & $63.5 \pm 9.9$ & $8.9 \pm 0.9$ & $7.9 \pm 0.5$ & $45 \pm 4$ \\
\hline 2 & $78 \pm 7$ & $70 \pm 6$ & $79.7 \pm 10.4$ & $8.9 \pm 0.6$ & $6.7 \pm 0.4$ & $37 \pm 3$ \\
\hline 3 & $77 \pm 7$ & $67 \pm 5$ & $79.3 \pm 6.2$ & $8.3 \pm 0.5$ & $6.4 \pm 0.6$ & $37 \pm 2$ \\
\hline \multicolumn{7}{|c|}{ Sodium-depleted dogs } \\
\hline $\mathrm{C}$ & $84 \pm 10$ & $66 \pm 4$ & $69.0 \pm 10.3$ & $9.1 \pm 0.8$ & $6.2 \pm 0.7$ & $34 \pm 4$ \\
\hline 1 & $98 \pm 6^{*}$ & $61 \pm 4$ & $52.0 \pm 4.0^{*}$ & $10.9 \pm 0.8$ & $6.8 \pm 0.7$ & $31 \pm 4$ \\
\hline 2 & $94 \pm 9$ & $65 \pm 5$ & $48.2 \pm 6.7^{*}$ & $9.4 \pm 0.6$ & $5.7 \pm 0.7$ & $30 \pm 3$ \\
\hline 3 & $90 \pm 6$ & $73 \pm 3$ & $47.2 \pm 6.6^{*}$ & $9.5 \pm 0.4$ & $5.8 \pm 0.7$ & $30 \pm 3$ \\
\hline
\end{tabular}

Values are means $\pm S E$ at a preinfusion control period $(C)$, and at 20 min during each of the successive saralasin infusions at rates of $0.05(1), 0.5(2)$, and $5.0(3) \mu \mathrm{g} / \mathrm{kg}$ per min. The numbers of experiments and body weights of the dogs are the same as in Table II.

* Values that are different from the control at $P<0.05$, as determined by Dunnett's test (32). 
attenuated responses to injected angiotensin I and II (Figs. 1 and 2).

Angiotensin II may produce cardiovascular changes indirectly by its actions on the central and peripheral sympathetic pathways. Centrally, angiotensin stimulates the area postrema, which modulates medullary vasomotor activity. In the peripheral sympathetic system, angiotensin has been shown to stimulate sympathetic ganglia and the adrenal medulla, to potentiate neurotransmitter biosynthesis and release, and to inhibit reuptake of norepinephrine at the nerve endings (37). Our arterial plasma norepinephrine measurements, however, did not indicate an increase in sympathetic activity during salt depletion. It appears likely that during high renin states angiotensin II acts to maintain normal arterial blood pressure by its direct vasoconstrictor action $(20,21)$.

Teprotide produced no systemic hemodynamic effects in normal dogs, suggesting that the reninangiotensin system plays no important role in maintaining arterial blood pressure in dogs on a regular sodium diet. In contrast, arterial blood pressure increased transiently in normal dogs during saralasin infusion, probably because of the partial agonist effect of saralasin. These results also indicate that neither agent has primary vasodepressor effects in normal dogs, and that the vasodilation produced by both agents in sodium-depleted dogs probably is related to the high angiotensin II level. Nevertheless, it may still be possible that a primary drug-induced vasodilation may occur during sodium depletion.

Cardiac output increased in salt-depleted dogs after teprotide administration and during saralasin infusion. This increase in cardiac output was associated with a decrease in mean aortic pressure, whereas neither left ventricular end-diastolic pressure nor myocardial contractility changed significantly. Vasodilators, such as nitroprusside, have been shown to increase cardiac output during heart failure (38). Nitroprusside, however, has no significant action on cardiac output in normal subjects (39), probably because it also dilates capacitance vessels and reduces the filling pressure of the heart, thus offsetting the effects of afterload reduction on cardiac output. Cardiac output, nevertheless, increases significantly in normal animals during nitroprusside infusion when the filling pressure of the heart is maintained (40). In our experiments in sodiumdepleted dogs, inhibition of angiotensin, which has its predominant effect on resistance vessels (18), decreased aortic blood pressure but had no effect on the left ventricular end-diastolic pressure. The decrease in aortic pressure may have been responsible for the increased cardiac output, as occurs when filling pressures are maintained during nitroprusside infusion, or after other maneuvers that reduce ventricular afterload without affecting the capacitance vessels $(41-43)$.

Previous investigators $(9,10)$ reported that cardiac output decreased in salt-depleted anesthetized rats after teprotide administration. However, in their experiments neither cardiac output nor systemic vascular resistance was altered by salt depletion, in apparent contradiction to our present study as well as the studies of others (2) in conscious dogs. Myocardial contractility was not measured in the rat experiments. The differences in species, degree of sodium depletion, and experimental methods might account for the variation in experimental results.

Coronary blood flow increased in salt-depleted dogs after angiotensin inhibition. The association of increased coronary blood flow with an increase in coronary sinus oxygen content and a decrease in myocardial oxygen extraction (Table III) suggests that an active coronary vasodilation occurred 20 min after teprotide administration. These effects of teprotide, however, are short-lived, because coronary blood flow returns toward control values after an additional $20 \mathrm{~min}$, although systemic and coronary vascular resistances are still decreased (unpublished observations). Likewise, coronary blood flow only increased significantly within the first 20 min of saralasin infusion; however, in this instance, the magnitude of the flow increase was small, and was not associated with significant narrowing of the coronary arteriovenous oxygen difference.

Coronary blood flow is determined largely by myocardial metabolic demand, which may offset the coronary vascular effects of neural or humoral mechanisms $(44,45)$. In the control state in these experiments, before angiotensin inhibition, coronary blood flow and diastolic vascular resistance in normal and sodium-depleted dogs did not differ. Thus, there was no evidence that sustained stimulation of the reninangiotensin system as a result of salt depletion and furosemide administration over a 5-day period influenced the normal relationship between coronary flow and myocardial metabolic demand. However, when the renin-angiotensin system was inhibited acutely by saralasin or teprotide in the salt-depleted animals, there was a prompt decrease in coronary vascular resistance and an increase in coronary blood flow. The findings suggest that the known vasoconstrictor effects of renin-angiotensin system activation upon the systemic vasculature are shared by the coronary vascular bed. This is consistent with the view that the coronary vessels are at least as sensitive to the constrictor effects of angiotensin as are vessels in skin and skeletal muscle (46). The increase in coronary blood flow produced by saralasin and teprotide, however, disappeared after $\mathbf{4 0} \mathrm{min}$ even 
while effects of angiotensin blockade upon peripheral vascular resistance and cardiac output persisted. The mechanism for this transient effect remains uncertain, but it probably relates to the dominant control of coronary blood flow by myocardial metabolic demand $(44,45)$. Neither left ventricular work nor myocardial oxygen consumption was changed significantly by renin-angiotensin system inhibition. The persistent low diastolic coronary vascular resistance during the late phase of angiotensin inhibition most likely represents a physiologic response of the coronary vasculature to maintain normal coronary blood flow in the presence of a reduced aortic diastolic pressure.

A decrease in aortic pressure may activate the baroreceptor reflex, which increases coronary blood flow by stimulating the myocardium to increase contractility and heart rate. Stimulation of cardiac sympathetic nerves also produces a direct constrictor effect on coronary vessels, but the indirect myocardial effects usually predominate (44). Massive sympathetic discharges probably did not occur as aortic pressure decreased during angiotensin inhibition in our experiments. Plasma norepinephrine concentration did not increase after teprotide administration, nor did myocardial contractility change significantly after administration of teprotide or saralasin. Heart rate increased only slightly 25-30 min after teprotide administration. In addition, the responsiveness of the efferent sympathetic nervous system of the baroreceptor reflex is decreased during salt depletion (47). It seems unlikely that sympathetic activation could have played a major role in causing the systemic and coronary hemodynamic changes observed in our study.

Teprotide is known to inhibit kininase and to augment the effects of bradykinin (14, 48, 49). Bradykinin exerts considerable vasodilator activity on systemic and coronary vascular beds. It decreases arterial pressure, and increases cardiac output and coronary blood flow in dogs $(18,50)$. Results of the present study, however, do not allow us to define the role of this bradykinin-potentiating effect of teprotide on systemic and coronary hemodynamics in normal and sodium-depleted dogs. The fact that both teprotide and saralasin produced qualitatively similar changes suggests that these effects are primarily the result of blockade of the renin-angiotensin system. The quantitative differences in the effects of teprotide and saralasin on systemic and coronary vascular resistances may be due to the slightly higher preinfusion control values in the teprotide groups, the partial agonist effects of saralasin, or the bradykinin-potentiating action of teprotide.

In summary, the present experiments show that activation of the renin-angiotensin system during sodium depletion contributes to circulatory homeostasis through vasoconstriction, but has no effect upon myocardial contractility or energetics. Under these conditions, blockade of the renin-angiotensin system lowers peripheral vascular resistance and arterial blood pressure, and increases cardiac output and coronary blood flow. Similar effects upon blood pressure have been demonstrated in patients with renin-dependent hypertension $(23,51,52)$ and, in patients with congestive heart failure, peripheral vascular resistance decreased and cardiac output increased $(53,54)$. However, extensive clinical experience with saralasin and teprotide is lacking, and the ultimate role which these agents may have in the therapy of hypertension or congestive heart failure is yet undefined. Inasmuch as saralasin and teprotide act by blocking intrinsic humoral mechanisms, which may in turn maintain vasomotor tone in key vascular beds such as the coronary circulation, they may possess therapeutic advantage over other currently available blood pressure-lowering agents. This may prove important in clinical states such as acute myocardial infarction and chronic ischemic heart disease.

\section{ACKNOWLEDGMENTS}

The authors thank Dr. Aram V. Chobanian for his careful review of the manuscript. We also thank Charles Scheller, Adele Rymut, Stephanie Arnold, Samuel Rivers, Song Que Lee, Norma Moolten, and Karen Rose for their technical assistance, and Deborah Walker for her secretarial help. The following chemicals were generously supplied by pharmaceutical companies: indocyanine green (CardioGreen) by Hynson, Westcott, \& Dunning, Inc., Baltimore, Md.; teprotide (SQ 20,881) by the E. L. Squibb Institute for Medical Research, Princeton, N. J.; and saralasin (P113) by Eaton Laboratories, Div. of The Norwich Pharmacal Company, Norwich, N. Y.

This study was supported in part by U. S. Public Health Service grants HL-18318, HL-14646, and NO 1 HV 53001 from the National Heart, Lung, and Blood Institute.

\section{REFERENCES}

1. Davis, J. O., and R. H. Freeman. 1976. Mechanisms regulating renin release. Physiol. Rev. 56: 1-56.

2. Mimran, A., L. Guiod, and N. K. Hollenberg. 1974. The role of angiotensin in the cardiovascular and renal responses to salt restriction. Kidney Int. 5: 348-355.

3. Steele, J. M., Jr., and J. Lowenstein. 1974. Differential effects of an angiotensin II analogue on pressor and adrenal receptors in the rabbit. Circ. Res. 35: 592600.

4. Johnson, J. A., and J. O. Davis. 1973. Effects of a specific competitive antagonist of angiotensin II on arterial pressure and adrenal steroid secretion in dogs. Circ. Res. 32 (Suppl. I): I-159-168.

5. Gavras, H., H. R. Brunner, E. D. Vaughan, Jr., and J. H. Laragh. 1973. Angiotensin-sodium interaction in blood pressure maintenance of renal hypertensive and normotensive rats. Science (Wash. D. C.). 180: 13691372.

6. Keeton, T. K., W. A. Pettinger, and W. B. Campbell. 1976. The effects of altered sodium balance and adrenergic 
blockade on renin release induced in rat by angiotensin antagonism. Circ. Res. 38: 531-539.

7. McCaa, R. E. 1977. Role of the renin-angiotensin system in the regulation of aldosterone biosynthesis and arterial pressure during sodium deficiency. Circ. Res. 40 (Suppl. I): I-151-162.

8. Haber, E., J. Sancho, R. Re, and A. C. Barger. 1975. The role of the renin-angiotensin system in cardiovascular homeostasis in normal man. Clin. Sci. Mol. Med. 48: 49s-52s.

9. Coleman, T. G., and A. C. Guyton. 1975. The pressor role of angiotensin in salt deprivation and renal hypertension in rats. Clin. Sci. Mol. Med. 48: 45s-48s.

10. Coleman, T. G., A. W. Cowley, Jr., and A. C. Guyton. 1975. Angiotensin and the hemodynamics of chronic salt deprivation. Am. J. Physiol. 229: 167-171.

11. McCaa, R. E. 1977. Aldosterone and blood pressure response to an orally active inhibitor of angiotensin I converting enzyme (SQ 14,225) in sodium deficient dogs. IRCS (Int.Res. Commun. Syst.) Med.Sci.-Libr. Compend. 5: 207.

12. Pals, D. T., F. D. Masucci, F. Sipos, and G. S. Denning, Jr. 1971. A specific competitive antagonist of the vascular action of angiotensin II. Circ. Res. 29: 664-672.

13. Needleman, P., J. R. Douglas, Jr., B. A. Jakschik, A. L. Blumberg, P. C. Isakson, and G. R. Marshall. 1976. Angiotensin antagonists as pharmacological tools. Fed. Proc. 35: 2488-2493.

14. Ondetti, M. A., N. J. Williams, E. F. Sabo, J. Pluščec, E. R. Weaver, and Q. Kocy. 1971. Angiotensin converting enzyme inhibitors from the venom of Bothrops jararaca: isolation, elucidation of structure, and synthesis. Biochemistry. 10: 4033-4039.

15. Ferguson, R. K., H. R. Brunner, G. A. Turini, and H. Gavras. 1977. A specific orally active inhibitor of angiotensin-converting enzyme in man. Lancet. I: 775-778.

16. Ondetti, M. A., B. Rubin, and D. W. Cushman. 1977. Design of specific inhibitors of angiotensin-converting enzyme: new class of orally active antihypertensive agents. Science (Wash. D. C.). 196: 441-444.

17. Peart, W. S. 1965. The renin-angiotensin system. Pharmacol. Rev. 17: 143-182.

18. Somlyo, A. P., and A. V. Somlyo. 1970. Vascular smooth muscle. II. Pharmacology of normal and hypertensive vessels. Pharmacol. Rev. 22: 249-353.

19. Koch-Weser, J. 1965. Nature of the inotropic action of angiotensin on ventricular function. Circ. Res. 16: 230-237.

20. Heyndrickx, G. R., D. H. Boettcher, and S. F. Vatner. 1976. Effects of angiotensin, vasopressin, and methoxamine on cardiac function and blood flow distribution in conscious dogs. Am. J. Physiol. 231: 1579-1587.

21. Dŕímal, J., K. Pávek, and F. V. Selecký. 1969. Primary and secondary effects of angiotensin on the coronary circulation. Cardiology. 54: 1-15.

22. Mimran, A., K. J. Hinrichs, and N. K. Hollenberg. 1974. Characterization of smooth muscle receptors for angiotensin: studies with an antagonist. Am. J. Physiol. 226: $185-190$.

23. Gavras, H., A. B. Ribeiro, I. Gavras, and H. R. Brunner. 1976. Reciprocal relation between renin dependency and sodium dependency in essential hypertension. N. Engl. J. Med. 295: 1278-1283.

24. Liang, C., and W. E. Huckabee. 1973. Mechanisms regulating the cardiac output response to cyanide infusion, a model of hypoxia. J. Clin. Invest. 52: 3115-3128.
25. Ramsey, L. H. 1959. Analysis of gas in biological fluids by gas chromatography. Science (Wash. D. C.). 129: 900-901.

26. Palmer, W. H., T. Zsoter, W. M. Fam, and $M$. McGregor. 1963. Measurement of coronary blood flow using 4-aminoantipyrine. Circulation. 28: 782. (Abstr.)

27. Liang, C. 1977. Metabolic control of circulation: effects of iodoacetate and fluoroacetate. J. Clin. Invest. 60: $61-69$.

28. Gorlin, R. 1961. Measurement of coronary flow in health and disease. In Modern Trends in Cardiology. A. M. Jones, editor. Paul B. Hoeber, Agathon Press, Inc., New York. 191-213.

29. Sealey, J. E., J. Gerten-Banes, and J. H. Laragh. 1972. The renin system: variations in man measured by radioimmunoassay or bioassay. Kidney Int. 1: 240-253.

30. Henry, D. P., B. J. Starman, D. G. Johnson, and R. H. Williams. 1975. A sensitive radio-enzymatic assay for norepinephrine in tissues and plasma. Life Sci. 16: 375-384.

31. Winer, B. J. 1971. Statistical Principles in Experimental Design. McGraw-Hill Book Company, New York. 2nd edition. 261-300.

32. Dunnett, C. W. 1964. New tables for multiple comparisons with a control. Biometrics. 20: 482-491.

33. Bailie, M. D., L. E. Davis, and R. Lautzenhiser. 1973. Intrarenal secretion of renin in the dog: effect of furosemide. Am. J. Physiol. 224: 425-430.

34. Chinn, R. H., and G. Düsterdieck. 1972. Response of blood pressure to infusion of angiotensin II: relation to plasma concentrations of renin and angiotensin II. Clin. Sci. (Oxf.). 42: 489-504.

35. Brunner, H. R., P. Chang, R. Wallach, J. E. Sealey, and J. H. Laragh. 1972. Angiotensin vascular receptors: their avidity in relationship to sodium balance, the autonomic nervous system, and hypertension. J. Clin. Invest. 51: 58-67.

36. Thurston, H., and J. H. Laragh. 1975. Prior receptor occupancy as a determinant of the pressor activity of infused angiotensin II in the rat. Circ. Res. 36: 113-117.

37. Zanchetti, A., and C. Bartorelli. 1977. Central nervous mechanisms in arterial hypertension: experimental and clinical evidence. In Hypertension: Physiopathology and Treatment. J. Genest, E. Koiw, and O. Kuchel, editors. McGraw-Hill Book Company, New York. 59-76.

38. Cohen, J. N., and J. A. Fransciosa. 1977. Vasodilator therapy of cardiac failure. Part I. N. Engl. J. Med. 297: $27-31$.

39. Cohn, J. N. 1973. Blood pressure and cardiac performance. Am. J. Med. 55: 351-360.

40. From, A. H. L., P. F. Carlyle, L. R. McGregor, M. E. Erickson, and J. N. Cohn. 1977. Effects of vasodilators on determinants of cardiac output in conscious dogs. Circulation. 56: III-129. (Abstr.)

41. Sagawa, K. 1967. Analysis of the ventricular pumping capacity as a function of input and output pressure loads. In Physical Bases of Circulatory Transport: Regulation and Exchange. E. B. Reeve and A. C. Guyton, editors. W. B. Saunders Co., Philadelphia. 141-149.

42. DuCharme, D. W., W. A. Freyburger, B. E. Graham, and R. G. Carlson. 1973. Pharmacologic properties of minoxidil: a new hypotensive agent. J. Pharmacol. Exp. Ther. 184: 662-670.

43. Wilcken, D. E. L., A. A. Charlier, J. I. E. Hoffman, and A. Guz. 1964. Effects of alterations of aortic impedance on the performance of the ventricle. Circ. Res. 14: 283-293.

44. Mark, A. L., and F. M. Abboud. 1975. Myocardial 
blood flow: neurohumoral determinants. In The Peripheral Circulations. R. Zelis, editor. Grune \& Stratton Inc., New York. 95-116.

45. Berne, R. M. 1975. Myocardial blood flow: metabolic determinants. In The Peripheral Circulations. R. Zelis, editor. Grune \& Stratton Inc., New York. 117-129.

46. Mark, A. L., F. M. Abboud, P. G. Schmid, D. D. Heistad, and H. E. Mayer. 1972. Differences in direct effects of adrenergic stimuli on coronary, cutaneous and muscular vessels. J. Clin. Invest. 51: 279-287.

47. Rocchini, A. P., J. R. Cant, and A. C. Barger. 1977. Carotid sinus reflex in dogs with low- to high-sodium intake. Am. J. Physiol. 233: H196-H202.

48. Ferreira, S. H., L. J. Greene, V. A. Alabaster, Y. S. Bakhle, and J. R. Vane. 1970. Activity of various fractions of bradykinin potentiating factor against angiotensin I converting enzyme. Nature (Lond.). 225: 379-381.

49. Rubin, B., E. H. O'Keefe, D. G. Kotler, D. A. DeMaio, and D. W. Cushman. 1975. Use of excised guinea pig ileum as a predictive test for inhibitors in vivo of angiotensin-converting enzyme (ACE). Fed. Proc. 34: 770. (Abstr.)
50. Haddy, F. J., T. E. Emerson, Jr., J. B. Scott, and R. M. Daugherty, Jr. 1970. The effect of the kinins on the cardiovascular system. In Handbook of Experimental Pharmacology. Vol. 25. Bradykinin, Kallidin, and Kallikrein. E. G. Erdös, editor. Springer-Verlag New York Inc., N. Y. 362-384.

51. Brunner, H. R., H. Gavras, J. H. Laragh, and R. Keenan. 1974. Hypertension in man: exposure of the renin and sodium components using angiotensin II blockade. Circ. Res. 34(Suppl. I): I-35-43.

52. Streeten, D. H. P., J. M. Freiberg, G. H. Anderson, and T. G. Dalakos. 1975. Identification of angiotensinogenic hypertension in man using 1-sar-8-ala-angiotensin II (saralasin, P-113). Circ. Res. 36(Suppl. I): I-125-132.

53. Gavras, H., A. Flessas, T. J. Ryan, H. R. Brunner, D. P. Faxon, and I. Gavras. 1977. Angiotensin II inhibition for the treatment of congestive cardiac failure in a highrenin hypertension. J.A.M.A. (J. Am. Med. Assoc.). 238: $880-882$.

54. Faxon, D. P., J. Berkoben, H. Gavras, A. P. Flessas, and J. T. Ryan. 1977. Angiotensin converting enzyme inhibition in patients with congestive heart failure. Circulation. 56: III-117. 